\title{
Producing Hydrogen in Sequential Dark and Photofermentation from Four Different Distillery Wastewaters
}

\author{
Roman Zagrodnik*, Krystyna Seifert, Mikołaj Stodolny, Anna Juszczak \\ Faculty of Chemistry, Adam Mickiewicz University, Poznań, Poland
}

Received: 1 August 2019

Accepted: 1 September 2019

\begin{abstract}
Four different distillery wastewaters were applied as the substrates for dark and photofermentation - wheat stillage (WTL), wheat syrup (WSR), maize stillage (MTL) and maize syrups (MSR). WTL was found to be the most effective substrate in dark fermentation, with a hydrogen production of $0.88 \mathrm{~L} \mathrm{H}_{2} / \mathrm{L}_{\text {medium }}$ and a yield of $1.17 \mathrm{~L} \mathrm{H}_{2} / \mathrm{L}_{\mathrm{wTL}}$. In the photofermentation experiments, the highest hydrogen production $\left(1.7 \mathrm{~L} \mathrm{H}_{2} / \mathrm{L}_{\text {medium }}\right)$ and the highest yield $\left(8.6 \mathrm{~L} \mathrm{H}_{2} / \mathrm{L}_{\mathrm{wSR}}\right)$ were obtained with WSR as the substrate A sequential two-step treatment, comprising dark fermentation followed by photofermentation, was applied to the same four substrates. WTL and MTL were the substrates for dark fermentation and the effluent after 5-fold dilution was used as the substrate in photofermentation. The maximum hydrogen production in the two-step system was $4.47 \mathrm{~L} \mathrm{H}_{2} / \mathrm{L}_{\mathrm{wTL}}$. Simultaneously, the organic compounds from the waste and those formed in dark fermentation were completely utilized, except for ethanol and methanol, which were $19 \%$ and $10 \%$ utilized, respectively.
\end{abstract}

Keywords: distillery wastewaters, dark fermentation, photofermentation, biohydrogen, two-step system

\section{Introduction}

Large-scale fermentative production of ethyl alcohol is mainly based on cane sugar, corn, potatoes and different kinds of grains serving as the sources of hydrocarbons. Production of ethyl alcohol from these substrates generates a significant amount of wastewater. In 2017 the production of ethanol in the United States was 1.02 million barrels per day and has been increasing year by year [1]. In Poland the annual production of ethyl alcohol reached one million hectoliters [2]. It

*e-mail: romzag@amu.edu.pl was estimated that the world demand for ethyl alcohol would increase by $70 \%$ in the next 10 years because of its application as a gasoline component [1]. Wastewaters coming from alcohol production, after drying, can be used for the cattle feed. However, the cost of the pretreatment is very high. Therefore, cheaper methods of utilization of the distillery wastewaters would have to be applied. Fermentative hydrogen production processes seem to be an attractive option, because they offer a dual function of waste reduction and hydrogen energy production [3, 4].

Although the application of different wastewaters from the food industry for hydrogen production in dark fermentation is well described in literature [5-9], the search for better yields, higher reaction rates 
and lower biomass production is still a challenge. The wide selection of substrates and microorganisms that can be used in the dark fermentation process opens a great chance for development of this method on a large scale. Recent papers [10-12] as well as our previous studies [13] can be a basis for microbiological hydrogen production with distillery wastewaters on a large scale. Wastewaters from the food industry can be used successfully also in photofermentative processes, where light-dependent heterotrophic bacteria decompose organic compounds, mainly volatile fatty acids, into hydrogen and carbon dioxide. Numerous papers [14-16] show that Rhodobacter sphaeroides can efficiently produce hydrogen from wastewaters coming from food industries like dairies, breweries, distilleries and others. Increasing the production of ethanol and bioethanol will result in higher amounts of waste, which will require efficient, environmentally friendly and economical methods of utilization. Combined systems, which link dark fermentation with photofermentation in a one- or two-step process, can lead to total biodegradation of organic compounds in waste and higher efficiency of hydrogen production than in separate processes.

The aim of this study was to compare four types of wastewaters coming from a local distillery (producing $113000 \mathrm{~m}^{3}$ waste/day) as the substrates for hydrogen production in dark fermentation, photofermentation and the two-step system. These wastewaters originated from different stages of ethanol production based on wheat and maize. Many publications have presented the production of hydrogen from distillery wastewaters [1720], but none have compared different types of distillery wastewaters. We would like to stress there have so far not been papers describing systems as mentioned above. This paper proves that in the two-step system the vast majority of organic compounds from wastewaters degrade completely to $\mathrm{H}_{2}$ and $\mathrm{CO}_{2}$ with high efficiency.

Table 1. Characteristic of wastewater.

\begin{tabular}{|c|c|c|c|c|}
\hline \multirow{3}{*}{ Properties } & \multicolumn{4}{|c|}{ Wastewater } \\
\hline & \multicolumn{2}{|c|}{ Wheat } & \multicolumn{2}{|c|}{ Maize } \\
\hline & WTL & WSR & MTL & MSR \\
\hline Total solid (TS) $[\mathrm{g} / \mathrm{mL}]$ & 0.128 & 0.136 & 0.130 & 0.234 \\
\hline \multicolumn{5}{|c|}{ Elemental anal. of TS } \\
\hline $\mathrm{C}[\%]$ & 48.8 & 45.8 & 48.9 & 47.1 \\
\hline $\mathrm{H}[\%]$ & 6.9 & 7.7 & 8.5 & 9.2 \\
\hline $\mathrm{N}[\%]$ & 6.5 & 7.1 & 4.1 & 2.6 \\
\hline $\mathrm{S}[\%]$ & 0.3 & 0 & 0.003 & 0.175 \\
\hline Total COD $\left[\mathrm{g} \mathrm{O}_{2} / \mathrm{L}\right]$ & 114 & 197 & 251 & 325 \\
\hline $\mathrm{COD}$ in solution $\left[\mathrm{g} \mathrm{O}_{2} / \mathrm{L}\right]$ & 43 & 86 & 13 & 58 \\
\hline $\operatorname{VSS}[\mathrm{g} / \mathrm{mL}]$ & 0.122 & 0.126 & 0.123 & 0.214 \\
\hline $\mathrm{pH}$ & 4.0 & 3.8 & 3.8 & 3.4 \\
\hline
\end{tabular}

\section{Experimental}

\section{Wastewaters}

Four different wastewaters originating from the processing of wheat and maize in the local distillery (Murowana Goślina, Poland) were substrates in the fermentation processes. These wastes were wheat stillage (WTL), wheat syrup (WSR), maize stillage (MST) and maize syrup (MSR). Stillages are a waste obtained after first distillation while syrups are obtained after decantation and condensation of stillages. Characteristics of the applied wastes are given in Tables 1 and 2.

\section{Inoculum}

In dark fermentation an anaerobic digested sludge originating from a municipal purification unit was used as an inoculum. In the pretreatment process it was boiled for 15 minutes to eliminate methanogenic bacteria. The total nitrogen content in inoculum (measured by Kjeldahl method) was $0.9 \mathrm{~g} / \mathrm{L}$, carbon content was $12.5 \mathrm{~g} / \mathrm{L}$ and the amount of volatile suspended solids (VSS) was $29.1 \mathrm{~g} / \mathrm{L}$.

In photofermentation Rhodobacter sphaeroides O.U.001 (ATCC 49419) bacteria were used. Bacteria were cultivated on Van Niel's medium containing $\mathrm{K}_{2} \mathrm{HPO}_{4}(1.0 \mathrm{~g} / \mathrm{L}), \mathrm{MgSO}_{4}(0.5 \mathrm{~g} / \mathrm{L})$, yeast extract $(10 \mathrm{~g} / \mathrm{L})$ and tap water filled up to $1 \mathrm{~L}$ and then activated to hydrogen production on modified Biebl and Pfennig medium according to the procedure already described [21].

\section{Medium and Procedure}

The medium used in dark fermentation contained $10,20,40,60$ or $75 \% \mathrm{v} / \mathrm{v}$ of distillery wastewaters. The medium was enriched with the following components (g/L): $1.0 \mathrm{NaHCO}_{3}, 0.5 \mathrm{NH}_{4} \mathrm{Cl}, 0.25 \mathrm{KH}_{2} \mathrm{PO}_{4}$,

Table 2. Organic compounds in wastewater.

\begin{tabular}{|c|c|c|c|c|}
\hline \multirow{2}{*}{$\begin{array}{c}\text { Compound } \\
{[\mathrm{g} / \mathrm{L}]}\end{array}$} & \multicolumn{4}{|c|}{ Wastewater } \\
\cline { 2 - 5 } & \multicolumn{2}{|c|}{ Wheat } & \multicolumn{2}{c|}{ Maize } \\
\cline { 2 - 5 } & WTL & WSR & MTL & MSR \\
\hline Glucose & 1.5 & 0 & 0.15 & 0 \\
\hline Lactic acid & 2.0 & 9.3 & 1.3 & 10.0 \\
\hline Acetic acid & 0.2 & 0.34 & 0.09 & 0.3 \\
\hline Butyric acid & 0 & 2.4 & 0 & 0.06 \\
\hline Malic acid & 0 & 3.8 & 0.3 & 2.3 \\
\hline Glycerol & 5.2 & 21.0 & 4.0 & 27.0 \\
\hline Succinic acid & 0.6 & 2.0 & 0.4 & 2.5 \\
\hline Methanol & 2.0 & 4.6 & 1.6 & 4.5 \\
\hline Ethanol & 0.08 & 0.04 & 0.04 & 0.2 \\
\hline
\end{tabular}


$0.25 \mathrm{~K}_{2} \mathrm{HPO}_{4}$, and $0.32 \quad \mathrm{MgSO}_{4} * 7 \mathrm{H}_{2} \mathrm{O} ; \quad$ and microelements $0.005 \mathrm{FeCl}_{3}, 0.0032 \mathrm{NiSO}_{4}, 0.005 \mathrm{CaCl}_{2}$, $0.0007 \quad \mathrm{Na}_{2} \mathrm{~B}_{4} \mathrm{O}_{7} * \mathrm{H}_{2} \mathrm{O}, \quad 0.0014 \quad\left(\mathrm{NH}_{4}\right)_{6} \mathrm{Mo}_{7} \mathrm{O}_{24} * 4 \mathrm{H}_{2} \mathrm{O}$, $0.0023 \mathrm{ZnCl}_{2}, 0.0021 \mathrm{CoCl}_{2} * 6 \mathrm{H}_{2} \mathrm{O}, 0.001 \mathrm{CuCl}_{2} * 2 \mathrm{H}_{2} \mathrm{O}$ and $0.003 \mathrm{MnCl}_{2} * 4 \mathrm{H}_{2} \mathrm{O}$. The medium with $75 \% \mathrm{v} / \mathrm{v}$ of wastes was not enriched with macro and micronutrients and consisted exclusively of non-diluted wastewaters and inoculum.

The experiments, run in $60 \mathrm{~mL}$ glass reactors (working capacity of $30 \mathrm{~mL}$ ), were performed in five-fold repetitions. The samples were inoculated with 10 or $25 \% \mathrm{v} / \mathrm{v}$ of inoculum (biomass content in inoculum: 2.5 or $6.4 \mathrm{~g} \mathrm{VS} / \mathrm{L}$, respectively). Initial $\mathrm{pH}$ was adjusted to 5.5. After deaeration of the samples with argon, all of them were sealed with butyl rubber membranes and incubated at $37^{\circ} \mathrm{C}$ with agitation (150 rpm). Medium containing $7 \mathrm{~g} / \mathrm{L}$ of glucose (standard medium) was applied as a reference.

In the photofermentation process distillery wastewaters replaced malic acid in modified Biebl and Pfennig medium and were introduced in 10, 20, 40, 60 or $70 \% \mathrm{v} / \mathrm{v}$. The process was carried out in $25 \mathrm{~mL}$ vials (working capacity of $12.5 \mathrm{~mL}$ ) made of borosilicate glass [19]. The medium was inoculated with $30 \% \mathrm{v} / \mathrm{v}$ of $R$. sphaeroides bacteria $(0.36 \mathrm{~g}$ dry $\mathrm{wt} / \mathrm{L})$. Process was performed at $30 \pm 2^{\circ} \mathrm{C}$. The initial $\mathrm{pH}$ was set to 7.0. The medium with $70 \% \mathrm{v} / \mathrm{v}$ of waste was not enriched with macro and micronutrients and consisted exclusively of non-diluted waste and inoculum.

In the two-step system, the effluent originating from dark fermentation was centrifuged (12500 rpm), sterilized, flushed with argon and sealed with butyl rubber septa; the initial $\mathrm{pH}$ was adjusted to 7.0-7.2. The samples prepared in this way were used in the photofermentation reactor. A mercury-tungsten lamp (Ultra-Vitalux 300W from Osram) with light intensity of $116 \mathrm{~W} / \mathrm{m}^{2}$ at the surface of reactors was used in all the experiments.

\section{Analytical Methods}

Gases were collected with a gas-tight syringe over the surface of liquid. Gas chromatography (Varian 3800 equipped with TCD and capillary column CARBOPLOT P7) was applied for measurements of hydrogen and carbon dioxide content in the final biogas. The operational temperatures at the injection port, in the oven and at the detector were 120,80 and $120^{\circ} \mathrm{C}$, respectively. Argon was used as a carrier gas flowing with the rate of $8 \mathrm{~mL} / \mathrm{min}$.

The concentrations of volatile fatty acids (VFAs) and alcohols was analyzed with HPLC (Ultimate 3000 from Dionex, ThermoScientific, SHODEX sugar column SH1011, RI detector, $1 \mathrm{~mL} / \mathrm{min}$ flow; eluent $5 \mathrm{mM} \mathrm{H} \mathrm{H}_{2}$ ). Each sample was centrifuged for 15 minutes at $12500 \mathrm{rpm}$ before the HPLC analysis. The loss of organic compounds ( $\Delta$ COD) was measured with a dichromate method [22]. The amount of total solids (TS) and volatile solids (VS) were determined according to the Standard Methods [22]. Ammonium ions concentration was measured applying MERCK spectroquant method (absorption at $690 \mathrm{~nm}$ ).

The biomass content was established spectrophotometrically by measuring the optical density at $660 \mathrm{~nm}$ (DU640 UV-VIS spectrophotometer from Beckmann). Elementary analysis for $\mathrm{C}, \mathrm{H}, \mathrm{N}, \mathrm{S}$ was performed by a Vario EL III elementary analyzer.

Substrate yield of hydrogen production was calculated as:

substrate yield $=\frac{\text { amount of } H 2 \text { produced in bioreactor }(L)}{\text { amount of wastewater in bioreactor }(L)}$

Specific yield of hydrogen production was calculated based on the following formula:

$$
\text { specific yield }=\frac{\text { amount of } H 2 \text { produced }(L)}{\text { amount of COD removed }(g C O D)}
$$

\section{Results and Discussion}

The analysis of wastewaters showed high COD in sediments as well as in the solutions, so both fractions could potentially serve as the substrates for dark fermentation. HPLC analysis showed that the syrups did not contain glucose but contained glycerin, organic acids and alcohols in concentrations substantially higher than the stillages (Table 2). Organic acids cannot serve as the substrates in dark fermentation, whereas they are the effective substrates in photofermentation. On the other hand, glucose and glycerin can be successfully used in dark fermentation.

\section{Hydrogen Production in Dark Fermentation}

In the experiments with distillery wastewaters coming from alcohol production based on wheat, inoculum in concentrations of 10 and $25 \% \mathrm{v} / \mathrm{v}$ were tested and the latter led to higher hydrogen production, therefore it was used in further studies.

Fig. 1 shows hydrogen production for different initial waste concentrations in the media for all tested wastewaters. The reference test with medium containing only inoculum (without any other nutrients) showed hydrogen production of $0.02 \mathrm{~mL} / \mathrm{L}$, which is represented in Fig. 1 as 'inoculum'. This value is very low so does not contribute to overall hydrogen production.

It can be clearly seen that when WTL was used, hydrogen production was 3- to 4-fold higher than with other wastes. This effect is caused by the glucose content in WTL waste (there is no or a very low concentration of glucose in all other tested wastewaters - Table 2). Glucose is easily assimilated by bacteria from digested sludge, carrying out dark fermentation, and easier than glycerin and methanol (in which concentrations are high in the syrups). Even though theoretically 4 moles of hydrogen can be produced from 1 mole of glucose, 


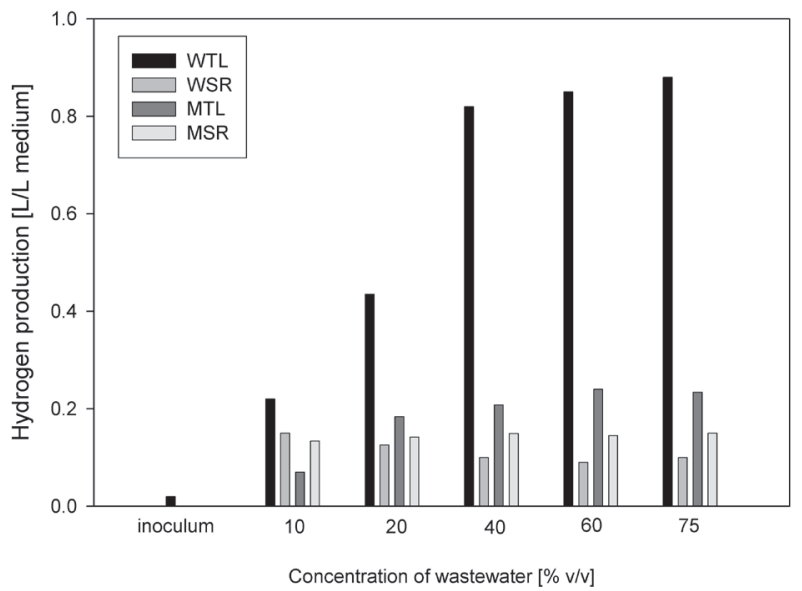

Fig. 1. Hydrogen production in dark fermentation carried out with distillery waste.

in practice maximum obtained values are around 2.7 moles, as glucose is also a growth substrate [5, 23]. WTL contains $1.5 \mathrm{~g} / \mathrm{L}$ of glucose. When $75 \% \mathrm{v} / \mathrm{v}$ of this waste was used in the medium, $0.88 \mathrm{~L} \mathrm{H}_{2} / \mathrm{L}_{\text {medium }}$ was produced. Assuming that the average value of hydrogen produced from 1 mole of glucose is 2.7 moles, $0.38 \mathrm{~L}$ $\mathrm{H}_{2} / \mathrm{L}_{\text {medium }}$ could be produced from glucose and the remaining $0.50 \mathrm{~L} \mathrm{H}_{2} / \mathrm{L}_{\text {medium }}$ from glycerin.

Previous studies have shown that the maximum consumption of glycerin by bacteria from digested sludge is $17 \mathrm{~g} / \mathrm{L}$ [24]. Glycerin can be transformed to organic acids and alcohols in two pathways: oxidative, where pyruvate and afterwards formate, ethanol, butyric acid and acetic acid are formed; and reducing, where 1,3-propandiol is the only product [25]. In our studies both pathways can be observed (Table 3), and additionally glucose and lactose are transformed to butyric and acetic acid as well as to ethanol and methanol.

Analysis of liquid metabolites, when WTL waste was used, showed that acetic, butyric and succinic acid as well as 1,3-propandiol were formed (Table 3). The final concentrations of these products indicated that they were formed mainly from the waste sediments (COD of liquid medium was only $38 \%$ of total COD of the waste). Glycerin and glucose contained in the liquid phase of the waste were completely consumed. However, lactic acid remained in the medium in up to $10 \%$ of initial concentration, while methanol was not consumed during the process. The concentration of succinic acid in the medium rose 5-fold and ethanol content increased over 3-fold.

Based on the above results, we can conclude that the main soluble substrates for microorganisms were glucose and glycerin, which were transformed to butyric and acetic acid as well as to 1,3-propanodiol. Analysis of the effect of waste content on hydrogen production showed that the amount of hydrogen increased significantly with the rising waste content in the medium in the range of $10-40 \% \mathrm{v} / \mathrm{v}$ (Fig.1, Table 4). A further increase of waste content resulted in only an insignificant rise of hydrogen production (up to $12 \%)$. Therefore, the yield of the process $\left(\mathrm{L} \mathrm{H}_{2} / \mathrm{L}_{\text {waste }}\right)$ decreased when the waste content in the medium was over $40 \% \mathrm{v} / \mathrm{v}$. Hydrogen content in final biogas varied from $48 \% \mathrm{v} / \mathrm{v}$ for MTL to $34 \% \mathrm{v} / \mathrm{v}$ for WSR (average value for dark fermentation around $50 \%[6,26])$.

The maximum amount of produced hydrogen $\left(0.88 \mathrm{~L} \mathrm{H}_{2} / \mathrm{L}_{\text {medium }}\right)$ was observed when $75 \% \mathrm{v} / \mathrm{v}$ WTL was introduced to the medium, which represented $70 \%$ of hydrogen production in standard medium $\left(1.2 \mathrm{~L} \mathrm{H}_{2} / \mathrm{L}\right.$ from $7 \mathrm{~g}$ glucose/L). Although four different distillery wastewaters were used in this study, only WTL gave

Table 3. Concentrations of main organic components in the liquid medium before and after fermentation of WTL waste with different dilutions.

\begin{tabular}{|c|c|c|c|c|c|c|c|c|}
\hline \multirow{2}{*}{$\begin{array}{c}\text { Metabolite } \\
{[\mathrm{g} / \mathrm{L}]}\end{array}$} & \multicolumn{2}{|c|}{$20 \%$} & \multicolumn{2}{|c|}{$40 \%$} & \multicolumn{2}{c|}{$60 \%$} & \multicolumn{2}{c|}{$75 \%$} \\
\cline { 2 - 11 } & Before & After & Before & After & Before & After & Before & After \\
\hline Glucose & 0.29 & 0 & 0.7 & 0 & 1.1 & 0 & 1.125 & 0.04 \\
\hline Lactic acid & 0.44 & 0.04 & 1.05 & 0.05 & 1.5 & 0.08 & 2.0 & 0.4 \\
\hline Acetic acid & 0.05 & 0.97 & 0.09 & 1.11 & 0.14 & 1.47 & 0.2 & 2.1 \\
\hline Butyric acid & 0 & 0.73 & 0 & 1.2 & 0 & 2.13 & 0 & 2.7 \\
\hline Malic acid & 0 & 0.03 & 0 & 0.11 & 0 & 0.13 & 0 & 0.2 \\
\hline Succinic acid & 0.12 & 0.60 & 0.30 & 1.08 & 0.40 & 2.14 & 0.45 & 3.56 \\
\hline Glycerol & 1.13 & 0.03 & 2.69 & 0 & 4.1 & 0 & 3.9 & 0 \\
\hline 1,3 -propanodiol & 0 & 0.59 & 0 & 1.48 & 0 & 4.42 & 0 & 6.30 \\
\hline Methanol & 0.48 & 0.61 & 0.61 & 0.39 & 1.42 & 1.58 & 2.47 & 2.32 \\
\hline Ethanol & 0.02 & 0.07 & 0.03 & 0.03 & 0.05 & 0.18 & 0.08 & 0.37 \\
\hline
\end{tabular}


Table 4. Results of dark fermentation of wheat and maize distillery wastewater.

\begin{tabular}{|c|c|c|c|c|}
\hline Waste content $[\% \mathrm{v} / \mathrm{v}]$ & $\begin{array}{c}\mathrm{H}_{2} \\
{\left[\mathrm{~L} / \mathrm{L}_{\text {medium }}\right]}\end{array}$ & $\begin{array}{c}\text { Substrate yield } \\
{\left[\mathrm{L} \mathrm{H}_{2} / \mathrm{L}_{\text {waste }}\right]}\end{array}$ & $\begin{array}{c}\mathrm{H}_{2} \\
{\left[\mathrm{~L} / \mathrm{L}_{\text {medium }}\right]}\end{array}$ & $\begin{array}{c}\text { Substrate yield } \\
{\left[\mathrm{L} \mathrm{H}_{2} / \mathrm{L}_{\text {waste }}\right]}\end{array}$ \\
\hline & \multicolumn{2}{|c|}{ WTL } & \multicolumn{2}{|c|}{ WSR } \\
\hline 10 & $0.22 \pm 0.02$ & 2.2 & $0.15 \pm 0.02$ & 1.5 \\
\hline 20 & $0.43 \pm 0.15$ & 2.18 & $0.13 \pm 0.02$ & 0.63 \\
\hline 40 & $0.82 \pm 0.10$ & 2.05 & $0.10 \pm 0.01$ & 0.25 \\
\hline 60 & $0.85 \pm 0.09$ & 1.42 & $0.09 \pm 0.01$ & 0.15 \\
\hline \multirow[t]{2}{*}{75} & $0.88 \pm 0.08$ & 1.17 & $0.10 \pm 0.01$ & 0.13 \\
\hline & \multicolumn{2}{|c|}{ MTL } & \multicolumn{2}{|c|}{ MSR } \\
\hline 10 & $0.07 \pm 0.01$ & 0.7 & $0.13 \pm 0.02$ & 1.3 \\
\hline 20 & $0.18 \pm 0.02$ & 0.92 & $0.14 \pm 0.02$ & 0.71 \\
\hline 40 & $0.21 \pm 0.02$ & 0.52 & $0.15 \pm 0.02$ & 0.37 \\
\hline 60 & $0.24 \pm 0.02$ & 0.4 & $0.15 \pm 0.02$ & 0.24 \\
\hline 75 & $0.23 \pm 0.02$ & 0.31 & $0.15 \pm 0.02$ & 0.2 \\
\hline
\end{tabular}

satisfactory results during the dark fermentation step. This showed that not all distillery wastewaters are a good substrate for biohydrogen production, because they can contain toxic compounds such as phenols and melanoidins, which inhibit dark fermentative bacteria $[17,20]$.

In our experiments, distillery wastewater with high COD content was used (at $75 \%$ dilution COD of WTL was $85 \mathrm{~g} \mathrm{O}_{2} / \mathrm{L}$ ). The observed hydrogen production was $1.17 \mathrm{~L} / \mathrm{L}_{\text {medium }}$ (equivalent of $7.4 \mathrm{mmol} \mathrm{H}_{2} / \mathrm{g} \mathrm{COD}_{\text {reduced }}$ ). For comparison, Mishra et al. [12] used distillery wastewater with $\mathrm{COD}$ of $40 \mathrm{~g} \mathrm{O}_{2} / \mathrm{L}$ and obtained $2.6 \mathrm{mmol} \mathrm{H}_{2} / \mathrm{g} \mathrm{COD}$ reduced, while Gadhe et al. [11] applied distillery wastewater with COD of $56 \mathrm{~g} \mathrm{O}_{2} / \mathrm{L}$ and observed maximum $\mathrm{H}_{2}$ production of $5.45 \mathrm{mmol}$ $\mathrm{H}_{2} / \mathrm{g} \mathrm{COD}_{\text {reduced }}$ This showed that in the case of WTL high hydrogen yields were obtained despite high COD value of the medium.

\section{Hydrogen Production in Photofermentation}

Media containing different concentrations of wheat and maize wastes (from 10-70\%) were tested in the photofermentation process with Rhodobacter sphaeroides O.U.001. The results of this set of experiments are shown in Table 5.

In the case of WTL photofermentation, the amount of produced hydrogen reached the maximum when $20 \% \mathrm{v} / \mathrm{v}$ WTL was applied and did not change above this concentration (Table 5). This could have been caused by increased COD and produced biomass, which could lead to worse light access inside the bioreactor. However, the most efficient option, as far as produced hydrogen $\left(1.1 \mathrm{~L} \mathrm{H}_{2} / \mathrm{L}_{\text {medium }}\right)$ and COD loss (5.79 $\left.\mathrm{g} \mathrm{O}_{2} / \mathrm{L}\right)$ are concerned, was medium containing $40 \%$ of WTL.

Table 5. Results of photofermentation with wheat and maize distillery wastewater.

\begin{tabular}{|c|c|c|c|c|c|c|}
\hline $\begin{array}{c}\text { Waste content } \\
{[\% \mathrm{v} / \mathrm{v}]}\end{array}$ & $\begin{array}{c}\mathrm{H}_{2} \\
{\left[\mathrm{~L} / \mathrm{L}_{\text {medium }}\right]}\end{array}$ & $\begin{array}{c}\text { Biomass } \\
{\left[\mathrm{g} / \mathrm{L}_{\text {medium }}\right]}\end{array}$ & $\begin{array}{c}\text { Substrate yield } \\
{\left[\mathrm{L} \mathrm{H}_{2} / \mathrm{L}_{\text {waste }}\right]}\end{array}$ & $\begin{array}{c}\mathrm{H}_{2} \\
{\left[\mathrm{~L} / \mathrm{L}_{\text {medium }}\right]}\end{array}$ & $\begin{array}{c}\text { Biomass } \\
{\left[\mathrm{g} / \mathrm{L}_{\text {medium }}\right]}\end{array}$ & $\begin{array}{c}\text { Substrate yield } \\
{\left[\mathrm{L} \mathrm{H}_{2} / \mathrm{L}_{\text {waste }}\right]}\end{array}$ \\
\hline & \multicolumn{3}{|c|}{ WTL } & \multicolumn{3}{|c|}{ WSR } \\
\hline 10 & $0.83 \pm 0.06$ & $1.54 \pm 0.17$ & 8.3 & $1.46 \pm 0.15$ & $1.85 \pm 0.17$ & 14.6 \\
\hline 20 & $1.06 \pm 0.20$ & $1.70 \pm 0.19$ & 5.0 & $1.72 \pm 0.18$ & $2.02 \pm 0.18$ & 8.6 \\
\hline 40 & $1.10 \pm 0.22$ & $1.94 \pm 0.21$ & 2.8 & $1.73 \pm 0.20$ & $2.17 \pm 0.19$ & 4.3 \\
\hline \multirow[t]{2}{*}{70} & $1.00 \pm 0.07$ & $1.90 \pm 0.17$ & 1.4 & $0.64 \pm 0.04$ & $2.47 \pm 0.27$ & 0.9 \\
\hline & \multicolumn{3}{|c|}{ MTL } & \multicolumn{3}{|c|}{ MSR } \\
\hline 10 & $0.63 \pm 0.07$ & $1.56 \pm 0.14$ & 6.3 & $1.67 \pm 0.23$ & $1.96 \pm 0.19$ & 6.7 \\
\hline 20 & $1.03 \pm 0.12$ & $1.86 \pm 0.20$ & 7.6 & $1.41 \pm 0.22$ & $2.04 \pm 0.18$ & 7.0 \\
\hline 40 & $1.09 \pm 0.09$ & $1.82 \pm 0.20$ & 2.7 & $1.37 \pm 0.16$ & $2.42 \pm 0.29$ & 3.4 \\
\hline 70 & $1.03 \pm 0.03$ & $1.98 \pm 0.16$ & 1.5 & $1.30 \pm 0.03$ & $1.98 \pm 0.13$ & 1.5 \\
\hline
\end{tabular}


When WSR was applied, the maximum hydrogen production was observed when 20 and $40 \% \mathrm{v} / \mathrm{v}$ of WSR were introduced to the medium and with $70 \% \mathrm{v} / \mathrm{v}$ WSR the amount of generated hydrogen dropped by over $60 \%$ (Table 5). Similarly as for WTL, increasing COD-produced biomass as well as increasing methanol content could be the reasons [27]. In conclusion, the most efficient option as far as produced hydrogen $\left(1.73 \mathrm{~L} \mathrm{H}_{2} / \mathrm{L}_{\text {medium }}\right)$ and COD loss $\left(21.6 \mathrm{~g} \mathrm{O}_{2} / \mathrm{L}\right)$ are concerned, was diluted medium contained $40 \%$ of WSR.

In most cases the distillery wastewaters need to be diluted before they can be used for photofermentation - mainly due to high concentrations of ammonium ions [15], which were found to inhibit nitrogenase and hence hydrogen production and increase the biomass concentration at the same time. Furthermore, high biomass content additionally reduces hydrogen production as it limits light penetration in the reactor. On the other hand, nitrogen limited conditions also reduce hydrogen production, and therefore it is important to achieve the balance between the amount of nitrogen necessary for bacterial growth and the amount that causes the reduction of hydrogen production.

Substrate yield and specific yield dropped significantly with rising waste content in the medium for both WTL and WSR. However, substrate yields were higher for photofermentation than for dark fermentation. Organic acids contained in the wheat wastes were more effective substrates in photofermentation than glucose and glycerin for dark fermentation. Hydrogen content in final biogas was in the range of $84-87 \%$, except when $70 \% \mathrm{v} / \mathrm{v}$ WSR was applied, where hydrogen content dropped to $65 \%$.

When MTL (Table 5) was applied, hydrogen production reached the maximum when $20 \% \mathrm{v} / \mathrm{v}$ MTL was applied and did not change above this concentration (similarly to WTL). The most efficient option, as far as produced hydrogen $\left(1 \mathrm{~L} \mathrm{H}_{2} / \mathrm{L}_{\text {medium }}\right)$ and COD loss
(5.88 $\left.\mathrm{g} \mathrm{O}_{2} / \mathrm{L}\right)$ are concerned, was medium containing $70 \%$ of MTL.

When MSR (Table 5) was applied, hydrogen production gradually decreased with rising waste content in the medium (in the range of $10-70 \%$ ). The reason for this effect could be very high COD in the crude waste (325 $\left.\mathrm{g} \mathrm{O}_{2} / \mathrm{L}\right)$ and high methanol content $(11.45 \mathrm{~g} / \mathrm{L})$. The highest hydrogen production was observed when MSR waste was 10-fold diluted (1.67 $\left.\mathrm{L} \mathrm{H}_{2} / \mathrm{L}_{\text {medium }}\right)$. High content of lactic acid in crude waste $(13.4 \mathrm{~g} / \mathrm{L})$ enabled high hydrogen production with only $10 \%$ of MSR in the medium. The highest COD loss (34.3 $\left.\mathrm{g} \mathrm{O}_{2} / \mathrm{L}\right)$ was obtained for $70 \% \mathrm{v} / \mathrm{v}$ MSR with simultaneous high hydrogen production - $1.03 \mathrm{~L} \mathrm{H}_{2} / \mathrm{L}_{\text {medium }}$. hydrogen content in final biogas was in the range of $80-87 \%$, except when $10 \%$ of MTL was applied, where hydrogen content dropped to $58 \%$.

Conversion of organic compounds in both wheatand maize-originating wastes in photofermentation are shown in Fig. 2. The complete transformation of succinic, lactic, acetic and malic acid was observed. Glucose, contained only in WTL, was $27 \%$ consumed. Glycerol concentration decreased in wheat wastes by $9-10 \%$ and in maize wastes remained almost unchanged. Methanol conversion in all four wastes was insignificant.

\section{Two-Step System}

Taking into account the content of the crude wastes and the products of dark fermentation, the two-step system, based on dark fermentation and photofermentation, was applied.

In the first step, where dark fermentation took place, hydrogen was produced from glucose and glycerol, which were $100 \%$ consumed. Simultaneously acetic, butyric, succinic and malic acid as well as 1,3-propandiol were formed, which served as the
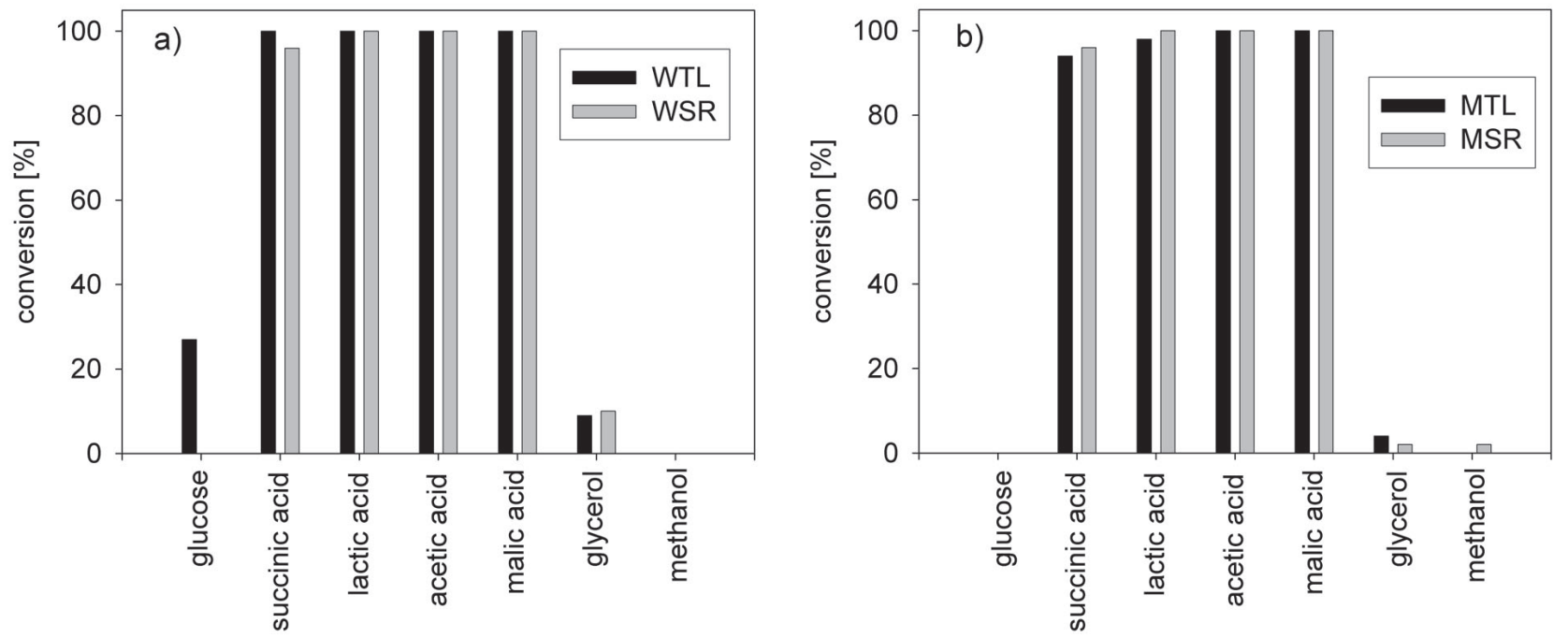

Fig. 2. Conversion of organic compounds during photofermentation: a) wheat distillery wastewater and b) maize distillery wastewater. 
Table 6. Hydrogen production in the two-step system; effluent from dark fermentation was 5-fold diluted before the photofermentation process.

\begin{tabular}{|c|c|c|c|}
\hline & $\begin{array}{c}\text { Dark } \\
\text { fermentation } \\
\text { I st step }\end{array}$ & $\begin{array}{c}\text { Photofermentation } \\
\text { II nd step }\end{array}$ & Total \\
\hline \multicolumn{3}{|c|}{$\left[\mathrm{L} \mathrm{H}_{2} / \mathrm{L}_{\text {medium }}\right]$} & 1.54 \\
\hline $\begin{array}{c}75 \% \mathrm{v} / \mathrm{v} \\
\mathrm{WTL}\end{array}$ & 0.88 & 0.66 & 0.71 \\
\hline $\begin{array}{c}75 \% \mathrm{v} / \mathrm{v} \\
\mathrm{MTL}\end{array}$ & 0.23 & 0.48 & 4.47 \\
\hline $\begin{array}{c}75 \% \mathrm{v} / \mathrm{v} \\
\mathrm{WTL}\end{array}$ & 1.17 & 3.30 & 2.71 \\
\hline $\begin{array}{c}75 \% \mathrm{v} / \mathrm{v} \\
\mathrm{MTL}\end{array}$ & 0.31 & 2.40 & $\left.\mathrm{~L} \mathrm{H}_{2}\right]$ \\
\hline
\end{tabular}

substrates for hydrogen production in photofermentation (second step of the hybrid system).

WTL and MTL led to the highest hydrogen production in dark fermentation and therefore these wastes were introduced to the medium (both in concentrations of $75 \% \mathrm{v} / \mathrm{v}$ ) in the first step. The effluent from the dark fermentation reactor was inoculated with Rhodobacter sphaeroides O.U.001 in 30\% v/v. The experiments showed that effluent had to be diluted 5 -fold in order for hydrogen production to take place. The reason for that could be the content of ammonium ions in the effluent: $1.08 \mathrm{~g} / \mathrm{L}$ coming from the digested sludge and $0.19 \mathrm{~g} / \mathrm{L}$ originating from the wastes. Sabourin-Provost et al. described the inhibiting effect of ammonium ions on photofermentation, proving that already as small a concentration as $2 \mathrm{mM}$ decreases hydrogen production [28, 29]. Other studies with distillery wastewaters in the two-step hybrid system showed that the effluent from dark fermentation has to be diluted at least five times before introducing it to the photofermentation reactor [17, 19]. The experiments with higher concentrations of the effluent from dark fermentation led to lower bacterial growth, hydrogen production and COD reduction. Laurinavichene et al. [19] reported maximum efficiency of hydrogen production (17.6 $\mathrm{L} \mathrm{H}_{2} / \mathrm{L}_{\text {waste }}$ ) with 5-fold diluted effluent, while Lazaro et al. [17] used 10-fold dilution to obtain maximum efficiency $\left(5.5 \mathrm{mmol} \mathrm{H}_{2} / \mathrm{g} \mathrm{COD}_{\text {reduced }}\right)$.

Average hydrogen production in dark fermentation of $75 \% \mathrm{v} / \mathrm{v}$ WTL was $0.88 \mathrm{~L} \mathrm{H}_{2} / \mathrm{L}_{\text {medium }}$, while in the second step (photofermentation) additionally $0.66 \mathrm{~L}$ $\mathrm{H}_{2} / \mathrm{L}_{\text {medium }}$ was generated. Therefore, the total amount of produced hydrogen in a two-step system was $1.54 \mathrm{~L}$ $\mathrm{H}_{2} / \mathrm{L}_{\text {medium }}$ (4.47 L $\mathrm{H}_{2} / \mathrm{L}_{\mathrm{wTL}}$, Table 6 ). When MTL in $75 \% \quad \mathrm{v} / \mathrm{v}$ was applied, $0.23 \quad \mathrm{~L} \quad \mathrm{H}_{2} / \mathrm{L}_{\text {medium }}$ was produced in dark fermentation and $0.48 \mathrm{~L} \mathrm{H}_{2} / \mathrm{L}_{\text {medium }}$ in photofermentation, which gave a total amount of $0.71 \mathrm{~L} \mathrm{H}_{2} / \mathrm{L}_{\text {medium }}\left(2.71 \mathrm{~L} \mathrm{H}_{2} / \mathrm{L}_{\mathrm{MTL}}\right)$.

In the separate processes of dark and photofermentation of WTL, $1.17 \quad \mathrm{~L} \quad \mathrm{H}_{2} / \mathrm{L}_{\text {WTL }}$ and $1.4 \mathrm{~L} \quad \mathrm{H}_{2} / \mathrm{L}_{\text {WTL }}$ were produced, respectively (2.57 L H $\mathrm{H}_{2} / \mathrm{L}_{\mathrm{WTL}}$ in total). Whereas in a two-step system $4.47 \mathrm{~L} \mathrm{H}_{2} / \mathrm{L}_{\text {WTL }}$ was produced in total, which was nearly 2 times higher than taking together the amount generated in two separate processes. When MTL was used for dark and photofermentation in the separate processes, total hydrogen production was $1.81 \mathrm{~L} \mathrm{H}_{2} / \mathrm{L}_{\mathrm{MTL}}\left(0.31 \mathrm{~L} \mathrm{H}_{2} / \mathrm{L}_{\mathrm{MTL}}\right.$ in dark fermentation and

Table 7. Examples of two-step systems in microbiological hydrogen production from waste.

\begin{tabular}{|c|c|c|c|c|c|}
\hline $\begin{array}{l}\text { Bacteria used } \\
\text { in dark fermentation }\end{array}$ & $\begin{array}{l}\text { Bacteria used in photofermen- } \\
\text { tation }\end{array}$ & $\begin{array}{l}\text { Origin of waste } \\
\text { (main substrates) }\end{array}$ & $\begin{array}{l}\text { Main substrates } \\
\text { in photofermentation }\end{array}$ & $\begin{array}{c}\mathrm{Max} \mathrm{H}_{2} \\
\text { production }\end{array}$ & Ref. \\
\hline $\begin{array}{l}\text { Heat-treated anaerobic } \\
\text { digested sludge }\end{array}$ & $\begin{array}{c}\text { Rhodobacter sphaeroides } \\
\text { O.U.001 }\end{array}$ & $\begin{array}{l}\text { Waste from chewing } \\
\text { gum production } \\
\text { (glycerol, Talha gum) }\end{array}$ & Xylitol, VFAs & $6.7 \mathrm{~L} / \mathrm{L}$ & [30] \\
\hline $\begin{array}{c}\text { Heat-treated anaerobic } \\
\text { digestion sludge (dominant } \\
\text { strain Clostridium butyri- } \\
\text { cum) }\end{array}$ & $\begin{array}{c}\text { Mixed photosynthetic bacteria } \\
\text { (dominant strain Rhodopseu- } \\
\text { domonas palustris) }\end{array}$ & $\begin{array}{l}\text { Cassava ethanol } \\
\text { wastewater }\end{array}$ & Acetate, butyrate & $5.2 \mathrm{~L} / \mathrm{L}$ & [31] \\
\hline Clostridium butyricum LS2 & $\begin{array}{c}\text { Rhodopseudomonas palustris } \\
\text { (1.8929) }\end{array}$ & Palm oil mill effluent & $\begin{array}{l}\text { VFAs (butyrate, } \\
\text { acetate, propionate), } \\
\text { ethanol }\end{array}$ & $3.1 \mathrm{~L} / \mathrm{L}$ & [32] \\
\hline Heat-treated sewage sludge & $\begin{array}{l}\text { Mixed bacterial culture HAU- } \\
\text { M1 }\end{array}$ & $\begin{array}{l}\text { Hydrolyzed corn } \\
\text { stover }\end{array}$ & VFAs & $7.0 \mathrm{~L} / \mathrm{L} / \mathrm{d}$ & [33] \\
\hline $\begin{array}{l}\text { Saccharolytic consortium } \\
\text { (silage pit liquid) }\end{array}$ & $\begin{array}{c}\text { Rhodobacter sphaeroides } \\
\text { B-3059, Rhodobacter capsu- } \\
\text { latus B10 }\end{array}$ & $\begin{array}{l}\text { Distillery wastewater } \\
\text { (saccharides, proteins, } \\
\text { VFAs - mainly lactate) }\end{array}$ & $\begin{array}{l}\text { VFAs (butyrate, ac- } \\
\text { etate, propionate) }\end{array}$ & $17.6 \mathrm{~L} / \mathrm{L}$ & [19] \\
\hline $\begin{array}{l}\text { Caldicellulosiruptor sac- } \\
\text { charolyticus }\end{array}$ & $\begin{array}{l}\text { Rhodopseudomonas palustris, } \\
\text { Rhodobacter capsulatus }\end{array}$ & $\begin{array}{l}\text { Sugar beet molasses } \\
\text { (sucrose) }\end{array}$ & $\begin{array}{l}\text { Acetate, lactate, } \\
\text { ethanol }\end{array}$ & $3.0 \mathrm{~L} / \mathrm{L}$ & [34] \\
\hline $\begin{array}{l}\text { Heat-treated anaerobic } \\
\text { digested sludge }\end{array}$ & $\begin{array}{c}\text { Rhodobacter sphaeroides } \\
\text { O.U.001 }\end{array}$ & $\begin{array}{l}\text { Distillery wastewater } \\
\text { (glucose, glycerol) }\end{array}$ & $\begin{array}{l}\text { VFAs (succinate, } \\
\text { butyrate, acetate), } \\
\text { ethanol, methanol }\end{array}$ & $4.47 \mathrm{~L} / \mathrm{L}$ & $\begin{array}{l}\text { [this } \\
\text { study] }\end{array}$ \\
\hline
\end{tabular}


$1.5 \mathrm{~L} \mathrm{H}_{2} / \mathrm{L}_{\mathrm{MTL}}$ in photofermentation). In the two-step process $\mathrm{H}_{2}$ production reached $2.71 \mathrm{~L} \mathrm{H}_{2} / \mathrm{L}_{\mathrm{MTL}}$. In the case of both WTL and MTL, total hydrogen production was significantly higher in the two-step system than for the separate processes [19, 30-34].

Table 7 presents the results on hydrogen production for two-step systems for different wastes with various substrates obtained by other researchers. It is difficult to compare the results when different substrates and different bacterial cultures were applied. However, we can refer to the systems where the dominant strain was $R$. palustris and acetate with butyrate were the main substrates for the photofermentation step [31, $32,34]$. In these systems, hydrogen production was in the range of $3.0 \mathrm{~L} / \mathrm{L}$ to $5.2 \mathrm{~L} / \mathrm{L}$, while $4.47 \mathrm{~L} / \mathrm{L}$ was obtained in our experiments. Lin et al. [31] using mixed bacterial cultures and cassava ethanol wastewater as a substrate obtained $0.43 \mathrm{~L} \mathrm{H}_{2} / \mathrm{L}$ and $4.77 \mathrm{~L} \mathrm{H}_{2} / \mathrm{L}$ in the dark and photo steps, respectively $(5.2 \mathrm{~L} \mathrm{H} / \mathrm{L}$ in total). High hydrogen production in the second step could be explained by high concentration of VFAs in dark fermentation effluent. A similar effect is observed in our experiments. In turn, Chandra et al. [18] obtained $1.51 \mathrm{~L} \mathrm{H}_{2} / \mathrm{L}$ from distillery wastewater during one step of hybrid dark-photo fermentation with mixed bacterial cultures as inoculum.

It is known that in dark fermentation, sugars are converted to VFAs, mainly to acetic and butyric acids [35]. High hydrogen production is observed when the ratio $\mathrm{HAc} / \mathrm{HBu}$ is high, namely when the acetic acid pathway is dominant [36]. Butyric and propionic acid pathways cause a decrease of hydrogen production [17]. In our experiments the main VFAs were acetic and butyric acids with an $\mathrm{HAc} / \mathrm{HBu}$ ratio varying between 1.3:1 to 0.7:1 (Table 3). Wang et al. [37] showed that hydrogen production rates and substrate conversion efficiency during photofermentation were improved for mixtures of acetic acid and butyric acids compared to processes with a single substrate. Therefore, mixtures of acetate and butyrate obtained after dark fermentation are beneficial for the second step of the hybrid system.

Indeed, an important advantage of the two-step process was a high utilization of organic compounds contained in the wastes, and also those formed in dark fermentation (1,3-propandiol, succinic, butyric, acetic and malic acid). When two separate processes of dark and photofermentation took place, 1,3-propandiol, organic acids, methanol and ethanol remained in the medium after dark fermentation, whereas glucose, glycerol and methanol remained in the medium after photofermentation. In the two-step system all the above-mentioned organic compounds were 100\% utilized, except ethanol and methanol, which were $18.9 \%$ and $9.5 \%$ utilized, respectively (Fig. 3). Similarly, Lin et al. [31] and Laurinavichene et al. [19] obtained $99 \%$ utilization of VFAs during the two-step process with distillery wastewater as a substrate. However, only $78 \%$ reduction of butyrate and increased acetate

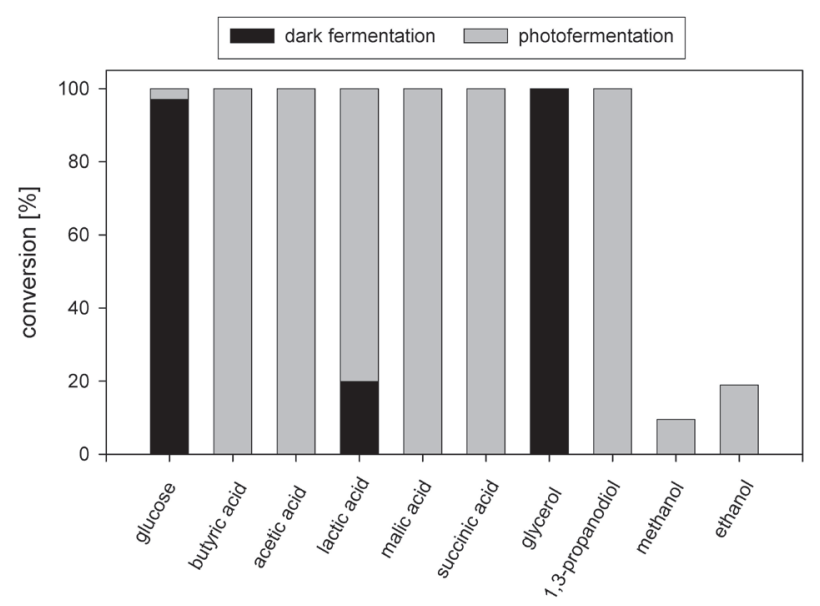

Fig. 3. Conversion of organic compounds in two-step system with WTL as a substrate.

concentration was observed in other two-step process with distillery wastewater [17], which was explained by the presence of toxic compounds and contamination by sulfur-reducing bacteria.

Combined biohydrogen production systems from distillery wastewaters presented by different studies (also single-step [18]) showed improved results compared to separate dark and photofermentation: higher hydrogen production as well as higher COD and VFA removal. Therefore, optimization of hybrid systems seems to be essential for application on a large scale. Our experiments were carried out in small bioreactors, and appropriate scale-up would be necessary to make the process economically viable. Most dark fermentation studies have been carried out at laboratory scale [38]. Limited studies have been performed on pilot-scale applications. More research on scalability is essential to provide information on feasible operating conditions, economic viability, reactor and plant design, as well as waste management. Dark fermentation processes have a prospect of being rapidly scaled-up owing to its similarity to the wellknown anaerobic digestion process. Recent studies on scaling-up dark fermentation usually showed showed only a slightly lower yield when compared to laboratory scale [38]. Considering the photofermentative process, one of its main disadvantages is the more complex design of reactors, owing to the need to maintain a suitable proportion between reactor surface area and volume when scaling-up. Moreover, the self-shading effect of bacteria cultures would affect abundance and homogeneous distribution of light. However, even in the case of photofermentation, efficient hydrogen production pilot bioreactors were presented [39].

\section{Conclusions}

Among four different distillery wastewaters only WTL gave high hydrogen yields, indicating that not all 
distillery wastewaters are suitable for dark fermentative hydrogen production. Based on our experiments, stillages were more effective substrates than syrups in dark fermentation as far as hydrogen production is concerned (by $80 \%$ in the case of wheat wastewater and by $40 \%$ in the case of maize wastewater). In contrast, the application of syrups during photofermentation led to $40 \%$ higher hydrogen production and over $70 \%$ higher COD loss in comparison with processes where stillages were used.

The combination of both dark and photofermentation in the two-step system gave two main advantages: 2-fold higher hydrogen production than for the separate processes and complete utilization of organic compounds contained in the wastes (glycerol, glucose and lactic acid) together with compounds formed in dark fermentation (1,3-propandiol, succinic, butyric, acetic and malic acid). The exception was ethanol and methanol, which were $18.9 \%$ and $9.5 \%$ utilized, respectively. Total hydrogen production in the two-step system reached $4.47 \mathrm{~L} \mathrm{H}_{2} / \mathrm{L}_{\mathrm{WTL}}$ and $2.71 \mathrm{~L} \mathrm{H}_{2} / \mathrm{L}_{\mathrm{MTL}}$.

\section{Acknowledgements}

This work was financed by the National Science Centre (grant No. UMO-2017/26/D/ST8/00149).

\section{Conflict of Interest}

The authors declare no conflict of interest.

\section{References}

1. U.S. fuel ethanol production continues to grow in 2017, Independent Statistics \& Analysis, U.S. Energy Information Administration, Today in Energy July 2017.

2. WOŹNIAK B. Statistic Poland, Production of industrial products in 2015-2018, Warsaw 2018, accessed 23.02.2020, www.stat.gov.pl

3. KESKIN T., ABO-HASHESH M., HALLENBECK P.C. Photofermentative hydrogen production from wastes. Bioresource Technology, 102 (18), 8557, 2011.

4. WANG J., YIN Y. Fermentative hydrogen production using various biomass-based materials as feedstock. Renewable and Sustainable Energy Reviews, 92, 284, 2018.

5. GHIMIRE A., FRUNZO L., PIROZZI F., TRABLY E., ESCUDIE R., LENS P.N.L., ESPOSITO G. A review on dark fermentative biohydrogen production from organic biomass: Process parameters and use of by-products. Applied Energy, 144, 73, 2015.

6. KOTHARI R., SINGH D.P., TYAGI V.V., TYAGI S.K. Fermentative hydrogen production - An alternative clean energy source. Renewable and Sustainable Energy Reviews, 16 (4), 2337, 2012.

7. Saad M.F.M., Rahman N.A., Yusoff M.Z.M. Hydrogen and methane production from co-digestion of food waste and chicken manure. Polish Journal of Environmental Studies, 28 (4), 2805, 2019.
8. YUSOF T.R.T., RAHMAN N.A., ARIFF A.B., MAN H.C. Evaluation of hydrogen and methane production from co-digestion of chicken manure and food waste. Polish Journal of Environmental Studies, 28 (4), 3003, 2019.

9. ARIMI M.M., KNODEL J., KIPROP A., NAMANGO S.S., ZHANG Y., GEISSEN S.-U. Strategies for improvement of biohydrogen production from organic-rich wastewater: A review. Biomass and Bioenergy, 75, 101, 2015.

10. INTANOO P., RANGSUNVIGIT P., NAMPROHM W., THAMPRAJAMCHIT B., CHAVADEJ J., CHAVADEJ $S$. Hydrogen production from alcohol wastewater by an anaerobic sequencing batch reactor under thermophilic operation: Nitrogen and phosphorous uptakes and transformation. International Journal of Hydrogen Energy, 37 (15), 11104, 2012.

11. GADHE A., SONAWANE S.S., VARMA M.N. Influence of nickel and hematite nanoparticle powder on the production of biohydrogen from complex distillery wastewater in batch fermentation. International Journal of Hydrogen Energy, 40 (34), 10734, 2015.

12. MISHRA P., DAS D. Biohydrogen production from Enterobacter cloacae IIT-BT 08 using distillery effluent. International Journal of Hydrogen Energy, 39 (14), 7496. 2014.

13. WICHER E., SEIFERT K., ZAGRODNIK R., PIETRZYK B., LANIECKI M. Hydrogen gas production from distillery wastewater by dark fermentation. International Journal of Hydrogen Energy, 38 (19), 7767, 2013.

14. KESKIN T., HALLENBECK P.C. Hydrogen production from sugar industry wastes using single-stage photofermentation. Bioresource Technology, 112, 131. 2012.

15. AL-MOHAMMEDAWI H.H., ZNAD H., EROGLU E. Improvement of photofermentative biohydrogen production using pre-treated brewery wastewater with banana peels waste. International Journal of Hydrogen Energy, 44 (5), 2560, 2019.

16. PALAMAE S., CHOORIT W., CHISTI Y. Continuous production of biohydrogen from oil palm empty fruit bunch hydrolysate in tubular photobioreactors. International Journal of Hydrogen Energy, 43 (34), 16497, 2018.

17. LAZARO C.Z., VARESCHE M.B.A., SILVA E.L. Sequential fermentative and phototrophic system for hydrogen production: An approach for Brazilian alcohol distillery wastewater. International Journal of Hydrogen Energy, 40 (31), 9642, 2015.

18. CHANDRA R., NIKHIL G.N., MOHAN S.V. Single-Stage Operation of Hybrid Dark-Photo Fermentation to Enhance Biohydrogen Production through Regulation of System Redox Condition: Evaluation with Real-Field Wastewater. International Journal of Molecular Sciences, 16 (5), 9540, 2015.

19. LAURINAVICHENE T., TEKUCHEVA D., LAURINAVICHIUS K., TSYGANKOV A. Utilization of distillery wastewater for hydrogen production in one-stage and two-stage processes involving photofermentation. Enzyme and Microbial Technology, 110, 1, 2018.

20. GADHE A., SONAWANE S.S., VARMA M.N. Evaluation of ultrasonication as a treatment strategy for enhancement of biohydrogen production from complex distillery wastewater and process optimization. International Journal of Hydrogen Energy, 39 (19), 10041, 2014.

21. WALIGÓRSKA M., SEIFERT K., SZYMAŃSKA K., ŁANIECKI M. Optimization of activation conditions of Rhodobacter sphaeroides in hydrogen generation process. Journal of Applied Microbiology, 101 (4), 775, 2006. 
22. APHA. Standard methods for the examination of water and wastewater. $21^{\text {st }}$ ed., Washington DC: American Public Health Association. 2005.

23. ELSHARNOUBY O., HAFEZ H., NAKHLA G., EL NAGGAR M.H. A critical literature review on biohydrogen production by pure cultures. International Journal of Hydrogen Energy, 38 (12), 4945, 2013.

24. SEIFERT K., WALIGORSKA M., WOJTOWSKI M., LANIECKI M. Hydrogen generation from glycerol in batch fermentation process. International Journal of Hydrogen Energy, 34 (9), 3671, 2009.

25. YAZDANI S.S., GONZALEZ R. Anaerobic fermentation of glycerol: a path to economic viability for the biofuels industry. Current Opinion in Biotechnology, 18 (3), 213, 2007.

26. WANG J., WAN W. Factors influencing fermentative hydrogen production: A review. International Journal of Hydrogen Energy, 34 (2), 799, 2009.

27. SALAKKAM A., WEBB C. The inhibition effect of methanol, as a component of crude glycerol, on the growth rate of Cupriavidus necator and other micro-organisms. Biochemical Engineering Journal, 98, 84, 2015.

28. ARGUN H., KARGI F., KAPDAN I.K. Light fermentation of dark fermentation effluent for bio-hydrogen production by different Rhodobacter species at different initial volatile fatty acid (VFA) concentrations. International Journal of Hydrogen Energy, 33 (24), 7405, 2008.

29. SABOURIN-PROVOST G., HALLENBECK P.C. High yield conversion of a crude glycerol fraction from biodiesel production to hydrogen by photofermentation. Bioresource Technology, 100 (14), 3513, 2009.

30. SEIFERT K., ZAGRODNIK R., STODOLNY M., ŁANIECKI M. Biohydrogen production from chewing gum manufacturing residue in a two-step process of dark fermentation and photofermentation. Renewable Energy, 122, 526, 2018.

31. LIN R., CHENG J., YANG Z., DING L., ZHANG J., ZHOU J., CEN K. Enhanced energy recovery from cassava ethanol wastewater through sequential dark hydrogen, photo hydrogen and methane fermentation combined with ammonium removal. Bioresource Technology, 214, 686, 2016.
32. MISHRA P., THAKUR S., SINGH L., AB WAHID Z., SAKINAH M. Enhanced hydrogen production from palm oil mill effluent using two stage sequential dark and photo fermentation. International Journal of Hydrogen Energy, 41 (41), 18431, 2016.

33. ZHANG Q., ZHANG Z., WANG Y., LEE D.-J., LI G., ZHOU X., GE X. Sequential dark and photo fermentation hydrogen production from hydrolyzed corn stover: A pilot test using $11 \mathrm{~m}^{3}$ reactor. Bioresource Technology, 253, 382, 2018.

34. ÖZGÜR E., MARS A.E., PEKSEL B., LOUWERSE A., YÜCEL M., GÜNDÜZ U., EROĞLU İ. Biohydrogen production from beet molasses by sequential dark and photofermentation. International Journal of Hydrogen Energy, 35 (2), 511, 2010.

35. CAI J., ZHAO Y., FAN J., LI F., FENG C., GUAN Y., TANG N. Photosynthetic bacteria improved hydrogen yield of combined dark- and photo-fermentation. Journal of Biotechnology, 302, 18, 2019.

36. NASR M., TAWFIK A., OOKAWARA S., SUZUKI M., KUMARI S., BUX F. Continuous biohydrogen production from starch wastewater via sequential dark-photo fermentation with emphasize on maghemite nanoparticles. Journal of Industrial and Engineering Chemistry, 21, 500, 2015.

37. WANG R., CUI C., JIN Y., LIU B., XING D., XIE G., REN N. Photo-fermentative hydrogen production from mixed substrate by mixed bacteria. International Journal of Hydrogen Energy, 39 (25), 13396, 2014

38. JARUNGLUMLERT T., PROMMUAK C., PUTMAI N., PAVASANT P. Scaling-up bio-hydrogen production from food waste: Feasibilities and challenges. International Journal of Hydrogen Energy, 43 (2), 634, 2018.

39. BORAN E., ÖZGÜR E., YÜCEL M., GÜNDÜZ U., EROGLU I. Biohydrogen production by Rhodobacter capsulatus Hup - mutant in pilot solar tubular photobioreactor. International Journal of Hydrogen Energy, 37 (21), 16437, 2012. 